\title{
Englacial drainage systems formed by hydrologically driven crevasse propagation
}

\author{
Douglas BENN, ${ }^{1,2}$ Jason GULLEY, ${ }^{1,3}$ Adrian LUCKMAN, ${ }^{4}$ Artur ADAMEK, ${ }^{5}$ \\ Piotr S. GLOWACKI ${ }^{6}$ \\ ${ }^{1}$ School of Geography and Geosciences, University of St Andrews, North Street, St Andrews, Fife KY16 8ST, UK \\ E-mail: Doug.Benn@unis.no \\ ${ }^{2}$ Department of Geology, The University Centre in Svalbard, PO Box 156, NO-9171 Longyearbyen, Norway \\ ${ }^{3}$ Department of Geological Sciences, PO Box 112120, 241 Williamson Hall, University of Florida, \\ Gainesville, Florida 32611-2120, USA \\ ${ }^{4}$ School of the Environment and Society, Swansea University, Singleton Park, Swansea SA2 8PP, UK \\ ${ }^{5}$ Faculty of Geodesy and Cartography, Warsaw University of Technology, 00-661 Warszawa, Poland \\ ${ }^{6}$ Department of Polar and Marine Research, Institute of Geophysics, Polish Academy of Science, 01-452 Warszawa, Poland
}

\begin{abstract}
Recent work has shown that surface-to-bed drainage systems re-form annually on parts of the Greenland ice sheet and some High Arctic glaciers, leading to speed-up events soon after the onset of summer melt. Surface observations and geophysical data indicate that such systems form by hydrologically driven fracture propagation (herein referred to as 'hydrofracturing'), although little is known about their characteristics. Using speleological techniques, we have explored and surveyed englacial drainage systems formed by hydrofracturing in glaciers in Svalbard, Nepal and Alaska. In Hansbreen, Svalbard, vertical shafts were followed through $\sim 60 \mathrm{~m}$ of cold ice and $\sim 10 \mathrm{~m}$ of temperate basal ice to a subglacial conduit. Deep hydrofracturing occurred at this site due to a combination of extensional ice flow and abundant surface meltwater at a glacier confluence. The englacial drainage systems in Khumbu Glacier, Nepal, and Matanuska Glacier, Alaska, USA, formed in areas of longitudinal compression and transverse extension and consist of vertical slots that plunge down-glacier at angles of $55^{\circ}$ or less. The occurrence of englacial drainages initiated by hydrofracturing in diverse glaciological regimes suggests that it is a very widespread process, and that surface-to-bed drainage can occur wherever high meltwater supply coincides with ice subjected to sufficiently large tensile stresses.
\end{abstract}

\section{INTRODUCTION}

Surface meltwater has long been known to reach the beds of temperate glaciers, where it is an important control on sliding speed (e.g. Iken and Bindschadler, 1986; Willis, 1995). It is now clear that surface meltwater can also penetrate ice that is below the pressure-melting point, and cause speed-ups on High Arctic glaciers (e.g. Copland and others, 2003; Vieli and others, 2004; Bingham and others, 2005) and parts of the Greenland ice sheet (Zwally and others, 2002; Joughin and others, 2008; Van de Wal and others, 2008). The possibility that climatic warming could cause both increased surface melting and accelerated transfer of ice to lower elevations has prompted renewed interest in englacial drainage systems as a key link between the surface and basal boundary conditions of ice sheets (Parizek and Alley, 2004).

The short time lag between the onset of surface melting and observed speed-up events indicates that the formation or reactivation of surface-to-bed drainage systems can occur on a timescale of days (Boon and Sharp, 2003; Bingham and others, 2005) or hours (Das and others, 2008). It is widely agreed that the only mechanism capable of establishing new surface-to-bed drainage systems on such timescales is the propagation of water-filled surface crevasses (Boon and Sharp, 2003; Catania and others, 2008; Das and others, 2008). Theoretical considerations indicate that hydrologically driven propagation of surface fractures will occur where a combination of tensile stresses and water pressure is large enough to overcome the fracture toughness of the ice (Röthlisberger and Lang, 1987; Van der Veen, 1998, 2007; Alley and others, 2005). Surface fractures can penetrate all the way to the glacier bed if water supply is great enough to fill the expanding fracture and offset freezing onto the walls. It has been argued that supraglacial ponds play a crucial role in this process, by providing an elevated head of water at the ice surface (Hagen and others, 1991; Boon and Sharp, 2003; Alley and others, 2005). Once established, fractures provide high hydraulic conductivity pathways through the glacier, which may then be enlarged into moulins by flowing water. If the fracture or moulin does not completely close during the winter months, it may be reactivated in the following melt season. In all important respects, the propagation of water-filled surface crevasses is similar to hydrofracturing of ice by pressurized subglacial water (e.g. Roberts and others, 2000; Bingham and others, 2005) in that water pressure at the crack tip is the crucial factor driving crack growth. Throughout this paper, we use the terms 'hydraulically driven fracture propagation' and 'hydrofracturing' interchangeably.

Several lines of evidence support the idea that fractures play a central role in the development of englacial drainage systems on many glaciers. First, moulins on glacier surfaces commonly occur in association with active or relict crevasses (e.g. Stenborg, 1969). Second, imaging of boreholes in Storglaciären, Sweden, has revealed the existence of numerous narrow, steeply plunging fracture-like passages, some of which contain slowly circulating water (Fountain 


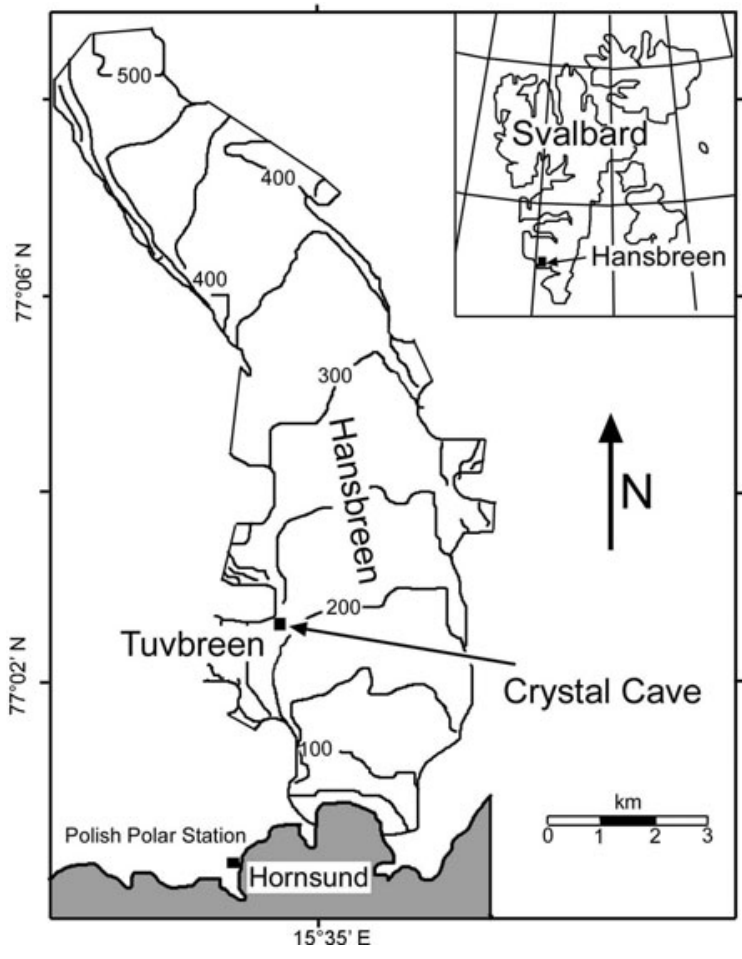

Fig. 1. Hansbreen, Svalbard, showing location of Crystal Cave.

and others, 2005). The origin of these features, however, and their relationship with englacial drainage evolution remain unclear. Third, rates of drainage of supraglacial ponds on John Evans Glacier, Ellesmere Island, Canada, are consistent with episodic englacial fracture propagation (Boon and Sharp, 2003). Fourth, concurrent supraglacial lake drainage, seismicity, ice uplift and increased horizontal motion have been documented at a site on the western flank of the Greenland ice sheet by Das and others (2008). Following complete lake drainage, two large moulins were observed in the lake floor, both located on fractures. Fifth, groundpenetrating radar surveys by Catania and others (2008) have revealed numerous deep vertical structures in areas of extending flow around Swiss Camp, west-central Greenland, interpreted as hydrologically overdeepened fractures. Finally, Gulley and Benn (2007) found that englacial conduits in the debris-covered Ngozumpa Glacier, Nepal, formed when supraglacial lakes drained through relict debris-filled crevasse traces.

Speleological exploration allows the morphology and evolution of englacial drainage systems to be studied in much greater detail than do surface-based methods. In this study, we use a combination of speleological and mountaineering techniques to explore and survey three englacial drainage systems in which hydrofracturing played a key role in passage formation. Two of the study sites are on polythermal glaciers: Hansbreen, Svalbard, and Khumbu Glacier, Nepal. The third is on the temperate Matanuska Glacier, Alaska, USA.

\section{METHODS}

Detailed surveys of englacial drainage systems were conducted at the end of the ablation season, when meltwater flow had largely ceased but passages remained fully open. The distance, azimuth and inclination between successive stations set in passage walls were measured using a Leica Disto $^{\mathrm{TM}}$ laser rangefinder and a Brunton SightMaster compass and inclinometer. Passage cross-section dimensions were measured at every survey station. Scaled sketches of all passages in plan, profile and cross-section were rendered in situ, including details of passage morphology and the structure of the surrounding ice. Survey data were reduced using the COMPASS software program, from which planimetrically accurate plans were drawn.

Patterns of strain in the ice were inferred at each site using a variety of methods. First, at Hansbreen, cumulative strains were determined by measuring the distance between pairs of markers installed in an englacial passage using a laser rangefinder on two occasions. Changes in distance were converted to logarithmic strain rates from:

$$
\dot{\varepsilon}=\frac{1}{\Delta t} \ln \left(\frac{L}{L_{0}}\right)
$$

where $L_{0}$ is the initial distance between two points, $L$ is the final distance and $\Delta t$ is the time interval between measurements (Hooke, 2005). Large-scale strain patterns were established for Khumbu Glacier using surface velocity fields derived from feature tracking on Advanced Spaceborne Thermal Emission and Reflection Radiometer (ASTER) imagery for the years 2001-05. At Matanuska Glacier, qualitative strain patterns were inferred from surface crevasses observed on Landsat imagery, based on the assumption that the principal tensile strain axis is normal to the trend of the crevasse.

\section{CRYSTAL CAVE, HANSBREEN Description}

Crystal Cave is an extensive englacial cave system located near the confluence of Hansbreen and Tuvbreen $\left(77^{\circ} 02^{\prime} 31^{\prime \prime} \mathrm{N}, 15^{\circ} 34^{\prime} 35^{\prime \prime} \mathrm{E}\right.$; Fig. 1). It was discovered in 1986 by J. Schroeder and has since been explored repeatedly by personnel based at the Polish research station at Hornsund (Pulina, 1984; Pulina and Rehak, 1991; Schroeder, 1995, 1998; Pälli and others, 2003). We conducted a comprehensive survey of all enterable parts of the cave in October 2006 and resurveyed part of the system in April 2007. In April 2007, the system was flooded to within $12.5 \mathrm{~m}$ of the surface (Fig. 2), indicating storage of at least $1.3 \times 10^{6} \mathrm{~m}^{3}$ of water over winter. Observations over several years indicate that passage flooding occurs annually during late winter and spring, particularly at times of rapid surface melt or rainfall.

Early each melt season, a supraglacial lake forms in a hollow between Hansbreen and Tuvbreen, and drains into the cave after breaking through a winter snow-dam. In winter 2006/07, the cave system had two entrances: (1) the lake entrance at the up-glacier end of the system; and (2) the moulin entrance, a vertical shaft at the down-glacier end. These two entrances were connected by a sub-horizontal passage trending approximately parallel to ice flow, generally $10-20 \mathrm{~m}$ below the glacier surface, off which led a series of vertical shafts. The sub-horizontal passage exhibited systematic changes in morphology down-glacier from the lake entrance (Fig. 2). In zone 1, it had a meandering canyon form with a plug of snow in the roof (Fig. 3a), whereas in zone 2 the passage consisted of a narrow vertical canyon with widespread evidence of wall convergence due to ice creep. In zone 3, the passage became more constricted, with 


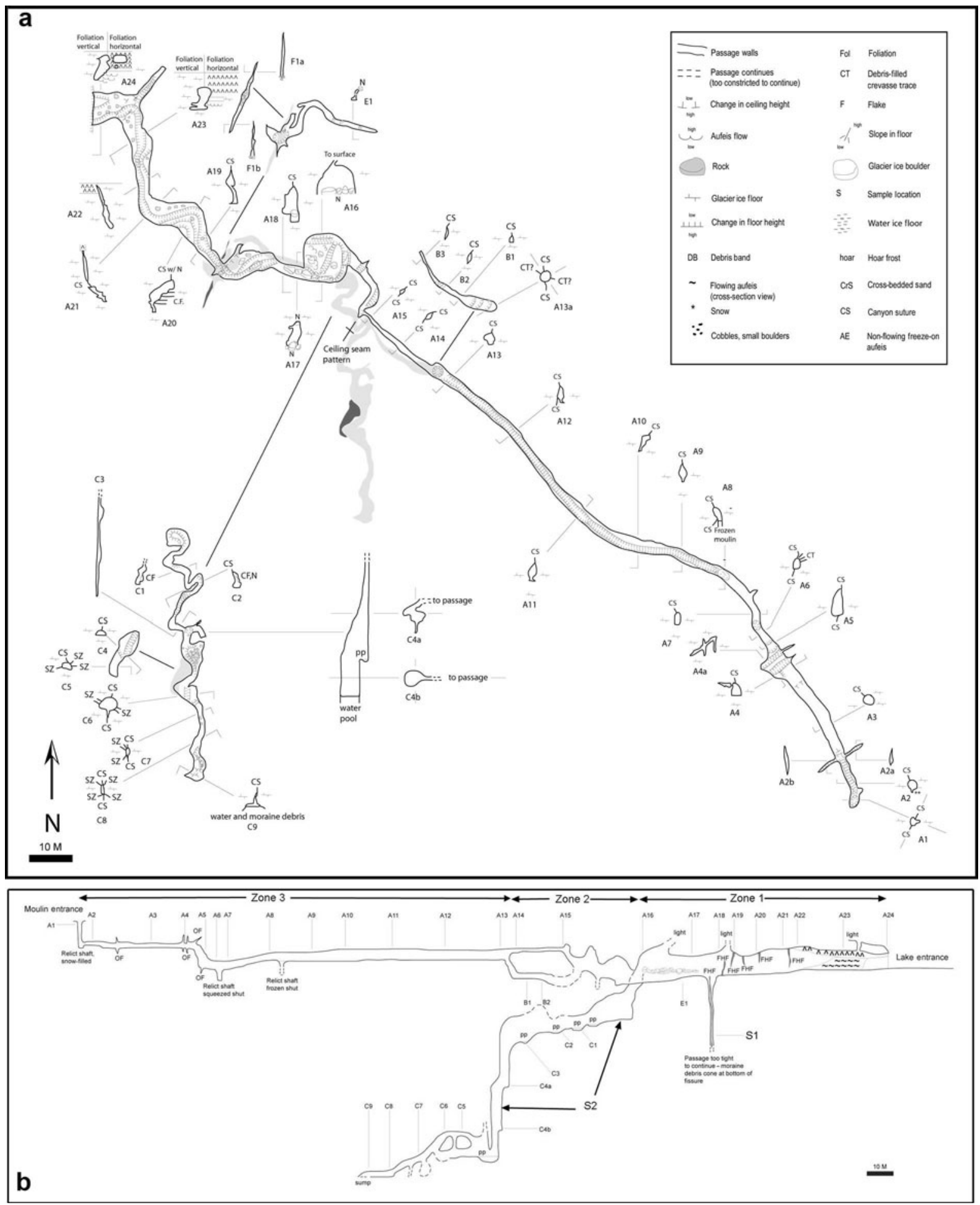

Fig. 2. Crystal Cave, Hansbreen, as surveyed in October 2006. (a) Plan view; (b) long profile, variable along conduit survey thalweg.

generally almond-shaped or circular cross-sections (Fig. 3c and d). The passage walls in zone 3 were coated by a skin of clear ice, likely formed by the freeze-on of water when the passage was flooded. In addition, episodes of freezing at times of partial passage flooding were recorded by horizontal 'false floors' and shelves of ice.

Repeated observations since 1986 indicate that the vertical shafts form close to the up-glacier end of the system and are subsequently modified as they are advected downglacier by ice flow. The youngest shaft (S1) formed during the summer of 2006 and extended downward from the floor of the upper passage, $58 \mathrm{~m}$ from the entrance (Figs 2 and $4 \mathrm{a}$ and $b$ ). The shaft consisted of a fresh vertical fracture striking $30^{\circ}$ transverse to the glacier flow direction, while the centre of the shaft had been enlarged by flowing water. Open fractures extended downwards and laterally from the top of the shaft, but were absent between the sub-horizontal passage and the surface. The horizontal distance from the centre of the shaft to the fracture tips increased with depth from $1.5 \mathrm{~m}$ at the top to $>8 \mathrm{~m} 25 \mathrm{~m}$ deeper. Vertical veins of clear ice adjacent to the fracture indicated that earlier fractures were subsequently infilled by refrozen meltwater. 

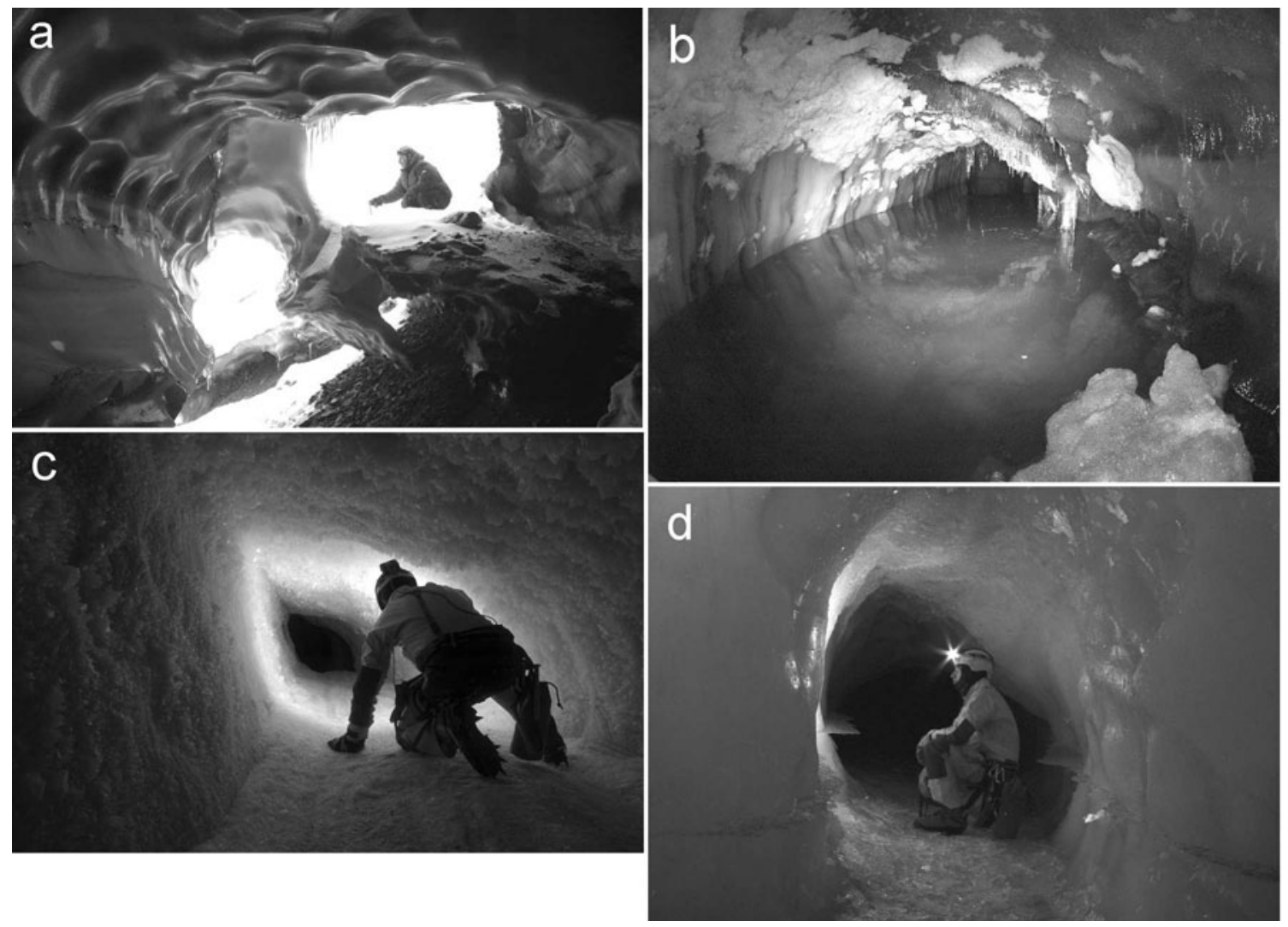

Fig. 3. Crystal Cave: upper passage. (a) Lake entrance, showing roof of névé and three holes where surface water entered the passage, October 2006. (b) Partially flooded passage in April 2006, looking down-glacier near A23. (c) Down-glacier end of passage near A14, October 2006. (d) Down-glacier end of passage near A7, April 2007. Note sills of ice on the walls recording partial flooding of the passage.

The bottom of the shaft, $48.6 \mathrm{~m}$ below the glacier surface, was floored with a mass of ice-cemented debris.

The second shaft (S2) was located $27 \mathrm{~m}$ further downglacier from S1 (Fig. 2a and b) and had a much more complex form. From the sub-horizontal passage (A16; Fig. 2a and b), a vertical step of $14 \mathrm{~m}$ led down into a meandering canyon with an overall strike of $170^{\circ}$. The floor of the canyon had relatively gently sloping reaches interrupted by short steps and plunge pools, and terminated at a final vertical moulin $\sim 30 \mathrm{~m}$ deep (Fig. $4 \mathrm{c}$ ). From a plunge pool at the base of the moulin $(\sim 64 \mathrm{~m}$ below the glacier surface) a passage led southward for $25 \mathrm{~m}$, where it reached the glacier bed $\sim 68 \mathrm{~m}$ below the glacier surface. The passage continued as a low wide partially water-filled conduit floored with till (Fig. 4d). Within $\sim 10 \mathrm{~m}$ of the bed, the walls of the passage were very wet and oozed water. The presence of wet ice close to the bed is consistent with ground-penetrating radar (GPR) evidence for a basal temperate ice layer below several tens of metres of cold ice in adjacent parts of Tuvbreen and Hansbreen (Moore and others, 1999). Measurements made in the cave system $\sim 10 \mathrm{~m}$ below the glacier surface in April 2007 indicated an ice temperature of $-1.2^{\circ} \mathrm{C}$.

Open or ice-filled fractures were visible in two locations in the vicinity of $\mathrm{S} 2$ : in the roof of the canyon near $\mathrm{C} 5$ and in the walls of the vertical moulin. The strike of the roof fracture was $\sim 30^{\circ}$ and consisted partly of a closed seam and partly of an open gap connecting with zone 2 of the upper passage (between A15 and A16; Fig. 2). Ice-filled fractures could be traced on opposite walls of the moulin, suggesting a strike of $35^{\circ}$.
The vertical shafts located in the more distal parts of the system generally had simple tubular cross-sections and extended either down or up from the sub-horizontal passage. Most of the shafts had blind terminations in ice or snow plugs; none extended down to the bed and only the 'moulin entrance' connected to the surface. Steep steps in the passage (e.g. at A5 and A13; Fig. 2) may also have originated as shafts. In all cases, a pair of vertical clear ice veins occurred in opposite walls of the shafts and steps. The veins were generally $\sim 1 \mathrm{~cm}$ across, parallel sided and cut cleanly across the ice foliation.

The longitudinal extension rate in the down-glacier part of the sub-horizontal passage was $0.034 \mathrm{a}^{-1}$ over a 178 day period between October 2006 and April 2007 (the initial distance between the markers was $35.469 \mathrm{~m}$ ). In the same time interval, this part of the passage underwent transverse compression of $-0.031 \mathrm{a}^{-1}$ (initial distance between markers $=1.791 \mathrm{~m}$ ). Longitudinal extension was also indicated by widespread transverse surface crevasses near the confluence of Hansbreen and Tuvbreen, and occasional open or ice-filled fractures in the passage walls. In October 2006, all of these fractures were too narrow to enter, but by April 2007 a fracture between A2 and A3 had widened sufficiently to permit exploration. The fracture was followed northeast for $2.5 \mathrm{~m}$, where it connected with a shaft extending both upward and downward. The top of the upper part of the shaft was blocked with snow, while the lower part dropped vertically for $19 \mathrm{~m}$ then terminated in a pool of water. The water level in the pool was $\sim 16 \mathrm{~m}$ lower than the water occupying the main passage at that time. 

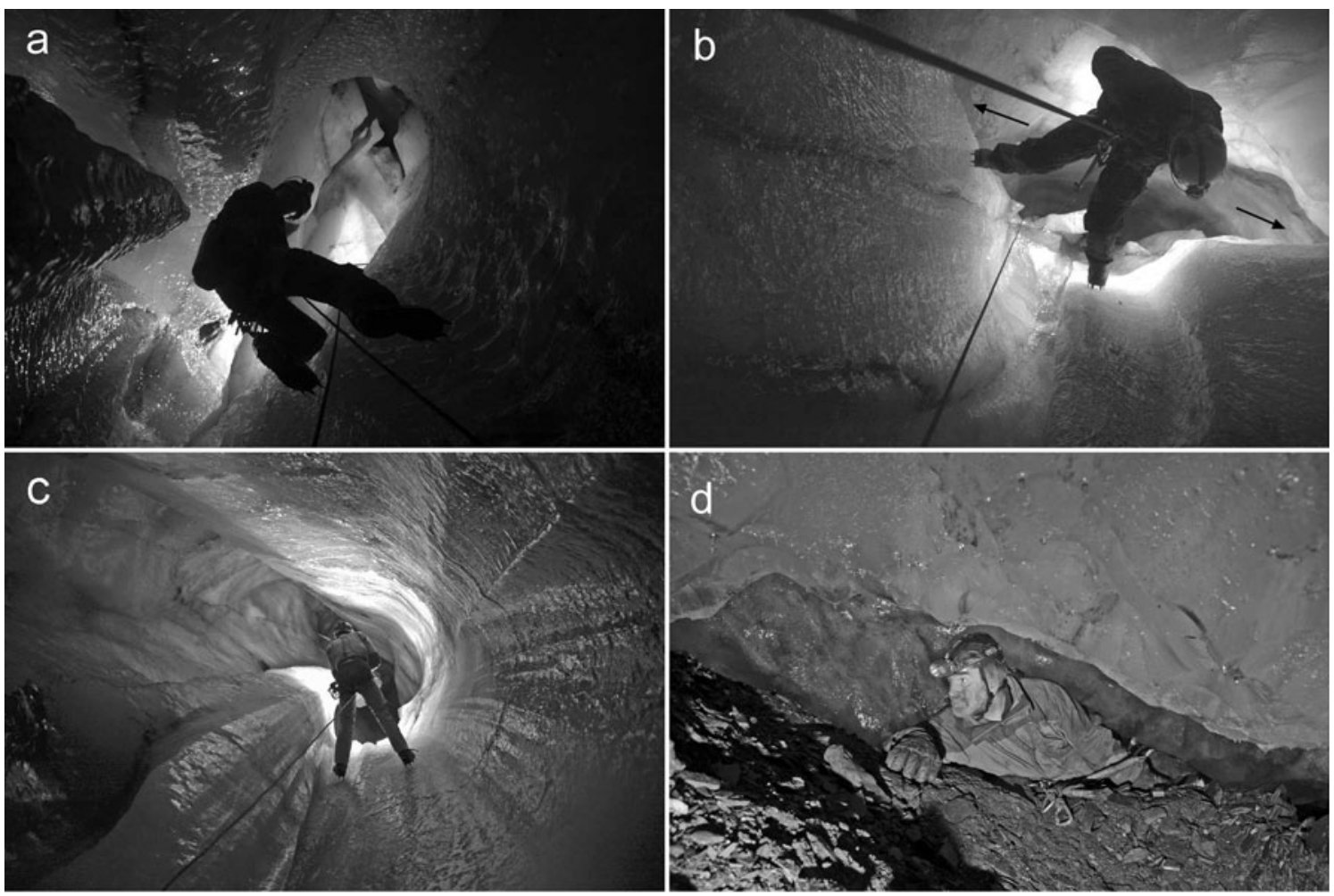

Fig. 4. Crystal Cave: shafts. (a) Moulin S1, October 2006. The fracture (behind the climber) extends downward and laterally from the upper passage. The moulin follows the central part of the fracture, where it has been enlarged by wall melting. (b) Looking down S1 from the upper passage, October 2006. Arrows indicate the fracture. (c) Vertical moulin, shaft S2, looking up, October 2006. (d) Gap between temperate basal ice and till bed, $68 \mathrm{~m}$ below the surface of Hansbreen, October 2006.

\section{Interpretation}

Our mapping indicates that all of the vertical shafts originated as locally overdeepened fractures. This is most clearly evident for the most recent shaft, S1, which is centred on a narrow vertical fracture trending approximately normal to the ice-flow direction. The highly localized nature of the fracture, which extends downward and laterally from the upper passage, leads us to conclude that water was a critical factor in fracture propagation. By offsetting the effects of ice pressure, water allowed the fracture to propagate much deeper than 'dry' crevasses on adjacent parts of the glacier. It is not known precisely when in the ablation season of 2006 this hydrofracturing event occurred. Break-up of the snow dam occurred in April of that year, following an anomalously early onset of spring melt (Fig. 3c), and fracturing apparently occurred later in the spring in response to rising water levels and pressure head. Vertical veins of clear ice adjacent to the fracture suggest that initial episodes of fracturing had failed to make a connection with the bed and water had frozen onto the walls.

Shaft S2 has been greatly modified by meltwater erosion since its formation, although the role of fracturing in initiating the system is clear. The moulin is centred on a relict fracture, indicating that it formed in a similar manner to $\mathrm{S} 1$, before the central part of the fracture was enlarged by flowing water and the lateral parts infilled with ice. The canyon above the moulin appears to have formed by stream incision and nick-point migration, although a deeper extension of the roof fracture near C5 may have played some role in determining the initial planform of the canyon. It is unclear whether this fracture formed at the same time as the moulin fracture or at a later date.
Strain-rate measurements and the presence of open fractures in the down-glacier part of the upper passage show that the ice remains under longitudinal extension and transverse compression in the relict part of the system. However, the second requirement for deep hydrofracturing fast recharge to fractures - is absent, since most inflowing water is captured by the shafts located up-glacier. The tubular shafts located in this part of the system are not associated with open fractures, although the paired vertical veins of clear ice in their sides are interpreted as former fractures infilled with refrozen meltwater. We argue that these older moulins were formed in a similar way to S1 and S2, but once they were cut off from their main water supply the parent fractures were healed by a combination of creep closure and adfreezing of meltwater. Through time, the relict moulins are advected down-glacier and become progressively modified in form (Stenborg, 1969; Holmlund, 1988).

The upper passage is interpreted as a closed supraglacial channel of the type described by Hansen (2001) and Gulley and others (2009). However, it is unlikely that water ever flowed along this channel for more than a few tens of metres from the lake basin. Water draining from the lake (and from the glacier surface after lake drainage) probably only followed the supraglacial channel (or its roofed-over englacial equivalent) as far as the nearest vertical shafts, whereupon water was diverted towards the bed. The more distal parts of the upper passage have been advected downglacier by ice flow, and their later evolution was dominated by passage closure by ice creep and refreezing of meltwater on the passage walls. It should be noted that Hansbreen has thinned by a few tens of metres during the last century and that more distal reaches of the upper passage would have 


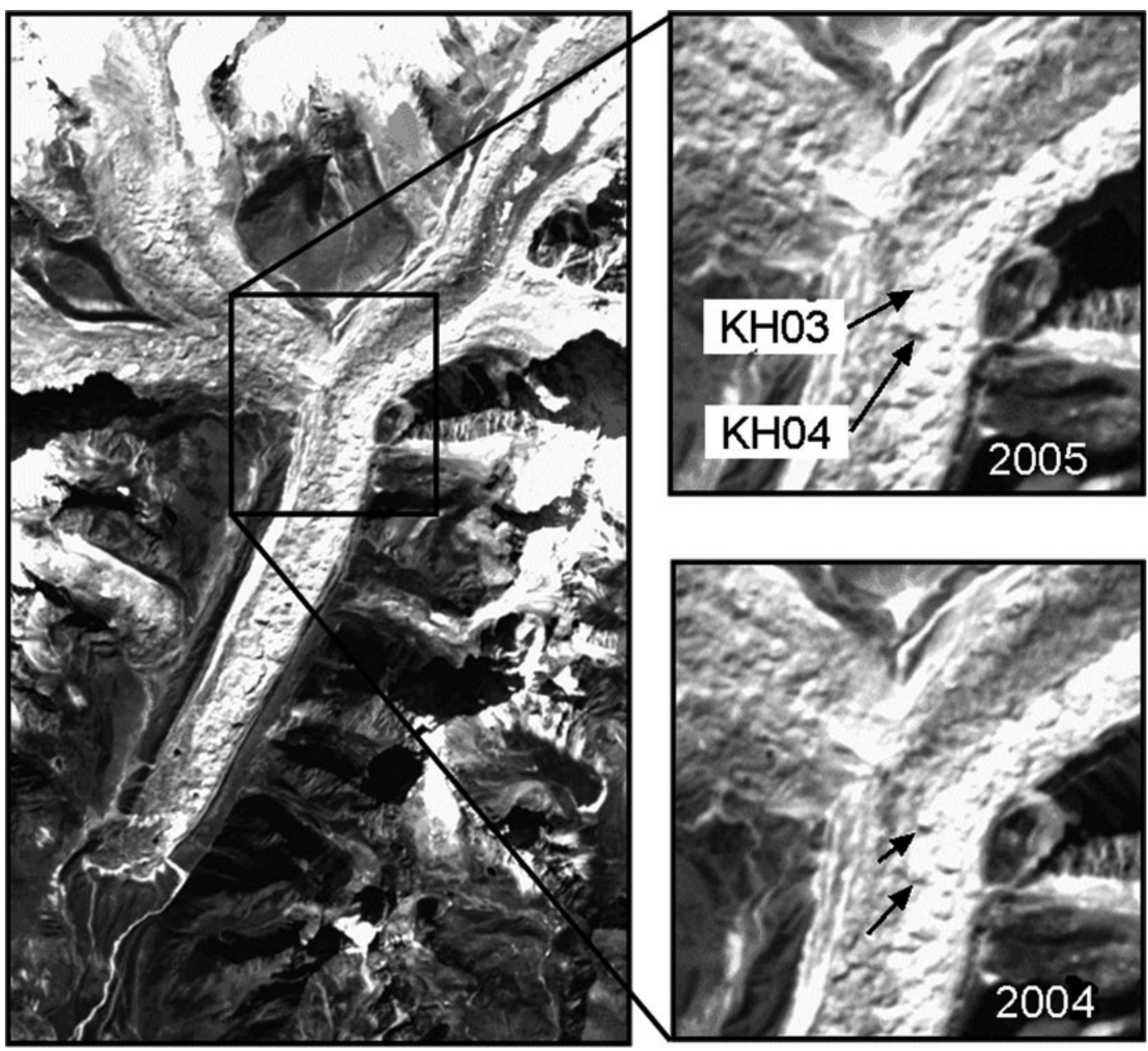

Fig. 5. Khumbu Glacier, showing the positions of $\mathrm{KHO}$ and $\mathrm{KHO4}$. The insets show that supraglacial ponds existed adjacent to $\mathrm{KH} 03$ in 2005 and KH04 in 2004.

been much deeper below the surface (as well as closer to earlier incarnations of the ephemeral lake) when they originally formed.

\section{KHUMBU GLACIER}

\section{Description}

Khumbu Glacier is a $16 \mathrm{~km}$ long debris-covered valley glacier in the upper Dudh Kosi catchment in Nepal. The main accumulation basin is in the Western Cwm, to the south of Qomolangma (Mount Everest), and ice flows through the Khumbu icefall to the ablation area where debris cover increases in areal extent and thickness towards the terminus at $\sim 4900 \mathrm{~m}$ a.s.l. (Fig. 5). The thermal regime of Khumbu Glacier is not well known. Measurements in shallow boreholes in the upper part of the ablation area in the 1970s indicated perennial cold ice in a surface layer $\sim 16 \mathrm{~m}$ thick and temperate ice at greater depths (Mae, 1976). Given the extreme altitude and low temperature of the glacier accumulation area, and rapid flow of ice through the Khumbu icefall, it is probable that cold ice is advected into the upper ablation zone. However, pronounced seasonal velocity variations in this area (Kodama and Mae, 1976; Seko and others, 1998; Nakawo and others, 1999) strongly suggest the existence of temperate basal ice beneath the icefall and upper ablation areas. We conclude that
Khumbu Glacier is probably polythermal with a cold nearsurface layer locally underlain by temperate ice (type D in the classification of Blatter and Hutter, 1991).

Two englacial passages associated with fractures were discovered in Khumbu Glacier. The first (KHO3: $27^{\circ} 58^{\prime} 21^{\prime \prime} \mathrm{N}$; $86^{\circ} 49^{\prime} 47^{\prime \prime} \mathrm{E}$ ) was on the down-glacier side of a large hollow in the glacier surface. ASTER imagery shows that this hollow was occupied by a supraglacial lake in December 2005 but drained sometime prior to our survey in December 2006 (Fig. 5). The former lake level was marked by a prominent erosional notch in an ice face $5 \mathrm{~m}$ above the cave entrance (Fig. 6a). The cave formed a vertical slot up to $30 \mathrm{~m}$ high and $8 \mathrm{~m}$ wide, and terminated in a series of alcoves floored by frozen ponds (Figs $6 \mathrm{~b}$ and 7). All parts of the passage walls had been eroded into dish-shaped scallop formations. A fresh open fracture extended the full height of the back of the passage and along the inner part of the ceiling, and an equivalent ice-infilled fracture was traced along the entire length of the floor. The strike of the fracture was $315^{\circ}$, parallel to the ice-flow direction. No open fractures or ice veins were visible between the glacier surface and the passage entrance.

The second passage ( $\left.\mathrm{KH04}: 27^{\circ} 58^{\prime} 15^{\prime \prime} \mathrm{N}, 86^{\circ} 49^{\prime} 45^{\prime \prime} \mathrm{E}\right)$ was located $\sim 170 \mathrm{~m}$ down-glacier of $\mathrm{KH03}$, also on the down-glacier side of a large supraglacial hollow (Fig. 5). The hollow was occupied by a supraglacial lake in 2004 and 2006, but not in 2005 when the site was first visited. In 


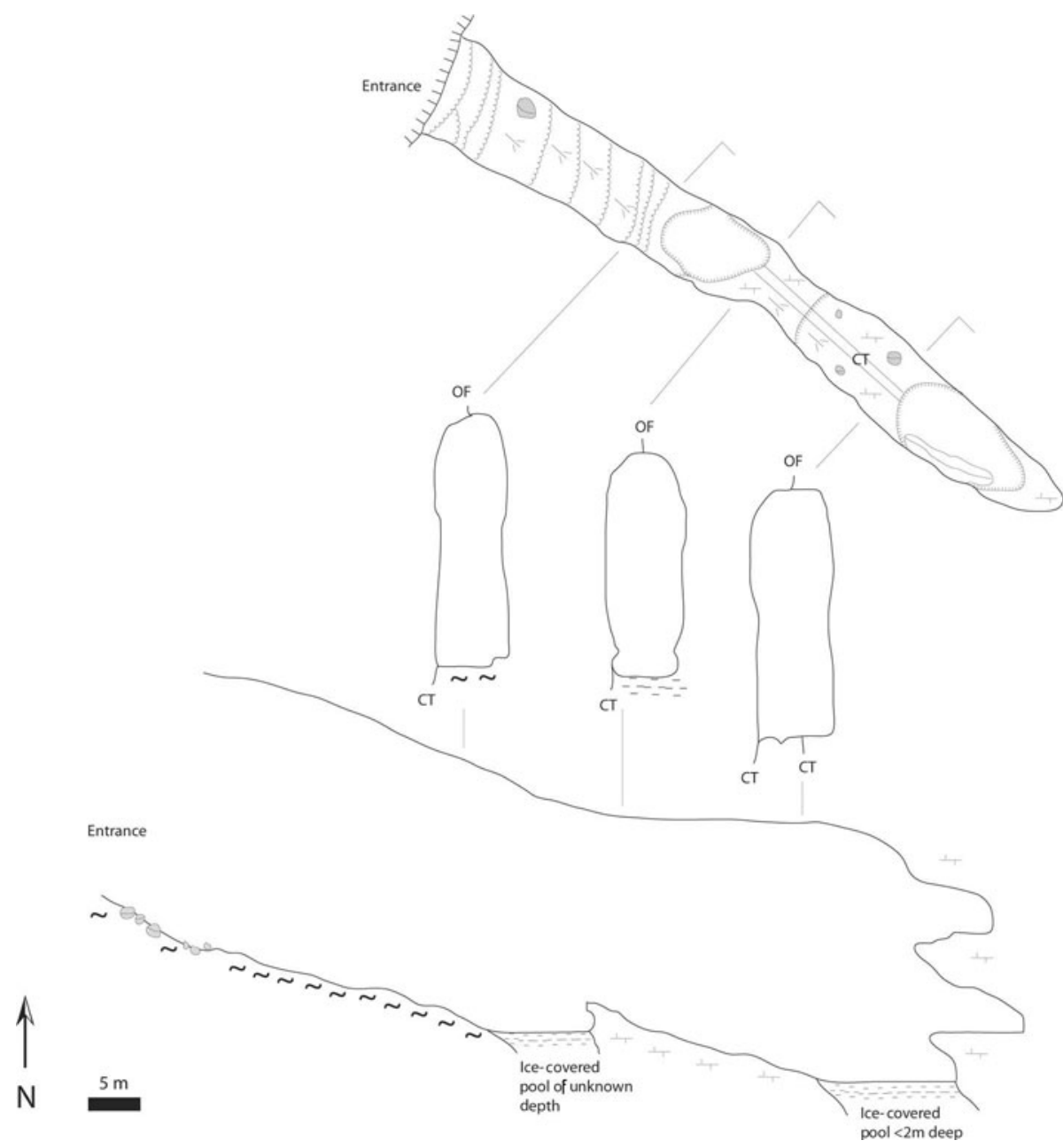

Fig. 6. KH03 on Khumbu Glacier, December 2006 plan view, long profile and cross-sections. CT: crevasse trace; OF: open fracture.

December 2005, KH04 had a bell-shaped cross-section nearly $35 \mathrm{~m}$ across, by far the largest sustained passage cross-sectional area of all caves investigated by us in the Himalaya (Fig. 6c). The single straight passage maintained consistent dimensions and plunged in a down-glacier direction for a distance of $120 \mathrm{~m}$ before terminating in a frozen pond. The passage floor consisted entirely of coarse bouldery debris similar to that on the glacier surface. In its innermost part, a subvertical fracture trace infilled with dirty ice could be seen in the passage ceiling, but closer to the entrance no obvious structural features were apparent. By December 2006, the basin was reoccupied by a lake. The entrance zone to $\mathrm{KHO} 4$ was still above water level and consisted of a wide arch $18 \mathrm{~m}$ high, the ceiling of which sloped back to water level $20 \mathrm{~m}$ from the entrance (Fig. 6d).

Feature tracking on ASTER imagery for the period 2001-05 shows that both $\mathrm{KHO} 3$ and $\mathrm{KHO} 4$ lie close to the up-glacier end of a zone of compressive flow, where active ice flowing from the Western Cwm decelerates against the slow-moving lower glacier tongue. Up-glacier of $\mathrm{KH} 03$, average velocities are around $10-15 \mathrm{~m} \mathrm{a}^{-1}$, whereas $1.5 \mathrm{~km}$ down-glacier they drop to $\sim 1.5-3.0 \mathrm{~m} \mathrm{a}^{-1}$ (Fig. 8). KHO4 lies within the zone of deceleration, whereas $\mathrm{KHO} 3$ lies just above its upper boundary. It is not possible to calculate strain rates at the two cave sites because the raw velocity data are rather noisy, mainly due to the influence of changes in the surface topography of the glacier between the two image-acquisition dates.

\section{Interpretation}

Both $\mathrm{KHO}$ and $\mathrm{KHO} 4$ are centred on longitudinal fractures, and both occur at the down-glacier margins of supraglacial hollows that were formerly occupied by lakes. We conclude that both englacial passages formed when a combination of longitudinal compressive stress and water pressure encouraged the development of hydrofractures and were then rapidly enlarged by thermally aggressive lake water. Supraglacial lakes on Himalayan glaciers can have water temperatures $>4^{\circ} \mathrm{C}$ (Chikita and others, 1999; Wessels and others, 2002; Hands, 2004), and heat advection during lake drainage can cause considerable enlargement of englacial conduits (Gulley and Benn, 2007). Fracturing appears to have proceeded in several stages, creating successively lower alcoves that were then enlarged by flowing water.

Our velocity data are not of sufficient resolution to allow strain patterns to be reconstructed in detail. However, the data are consistent with net (deviatoric) compressive stresses in the glacier flow direction and tensile deviatoric stresses in the transverse direction. The deviatoric stress in any direction $\sigma_{i i}^{\prime}$ is defined as the applied stress in that direction $\sigma_{i i}$ minus the mean normal stress:

$$
\sigma_{i i}^{\prime}=\sigma_{i i}-1 / 3\left(\sigma_{x x}+\sigma_{y y}+\sigma_{z z}\right) .
$$

If all three normal stresses are compressive but unequal, at least one of the deviatoric stresses will be tensile. If the ice is 


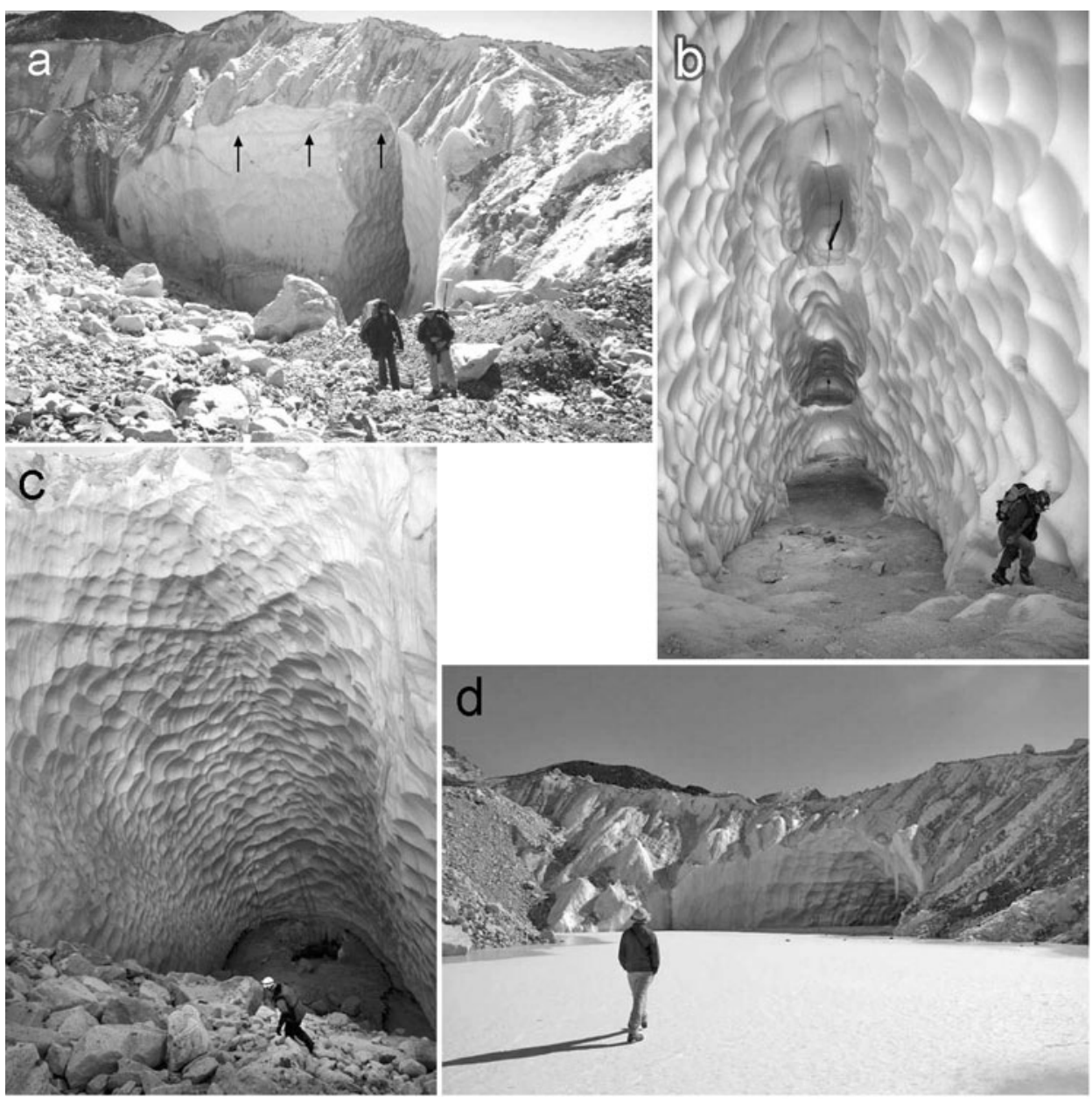

Fig. 7. $\mathrm{KHO3}$ and $\mathrm{KH} 04$. (a) View of lake basin and the entrance of KH03, December 2006. Note the notch above the cave entrance marking the former lake level (arrows). (b) View into KH03 showing the roof fracture and scalloped walls, December 2006. (c) KH04, November 2005. (d) KH04, December 2006.

constrained laterally, it might be expected that a tensile stress will develop in the vertical direction. However, on Khumbu Glacier there are deep swales along both lateral margins allowing ice in the central part to spread laterally. We infer that compressive stresses in the down-glacier direction associated with flow deceleration result in a transverse tensile deviatoric stress. This is not large enough

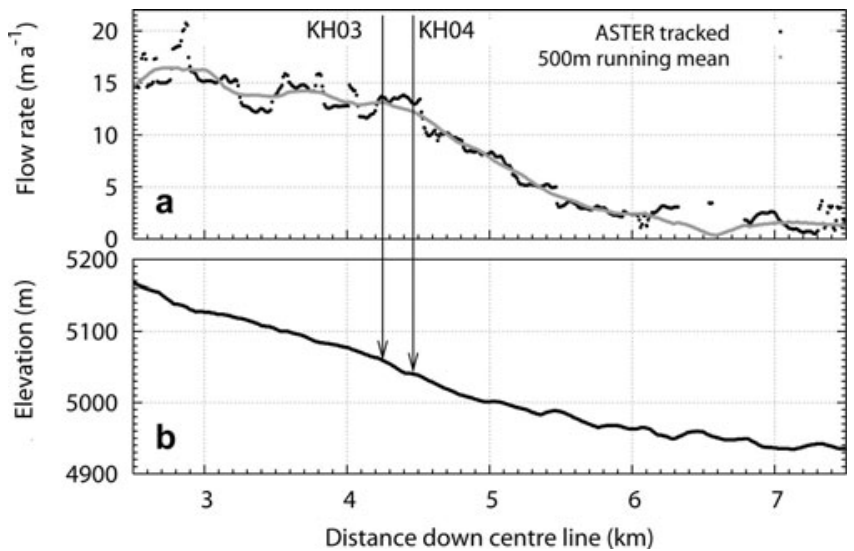

Fig. 8. (a) Mean annual surface velocities on Khumbu Glacier, 2001-05: tracked velocities and $500 \mathrm{~m}$ running mean. (b) Surface profile, showing locations of $\mathrm{KHO}$ and $\mathrm{KH} 04$. to initiate open surface crevasses, but in combination with elevated water pressure below the margins of supraglacial lakes appears to have been sufficient to initiate fracturing.

We conclude that hydrofracturing occurs repeatedly in this region of the glacier, when supraglacial lake basins develop in, or are advected by ice flow into, the zone of compression. Fracturing allows thermally aggressive water to enter the glacier, rapidly enlarging the englacial passage and encouraging complete lake drainage.

\section{MATANUSKA GLACIER Description}

Matanuska Glacier is a $43 \mathrm{~km}$ long temperate valley glacier flowing northward from the Chugach Mountains in southcentral Alaska. The terminal zone began advancing about September 2002, impacting stagnant buried ice (Baker and others, 2003; Chesley and others, 2005). Longitudinal crevasses extend $\sim 2 \mathrm{~km}$ up-glacier from the terminus, above which is unfractured ice with a well-developed supraglacial stream network (Fig. 9). Up-glacier dipping transverse crevasses interpreted as thrust faults occur near the terminus, some of which are associated with vents discharging supercooled water (Alley and others, 1998; Lawson and others, 1998). The combination of these structural features leads us to characterize the stress field of the crevassed glacier tongue as longitudinal compression and transverse extension. 


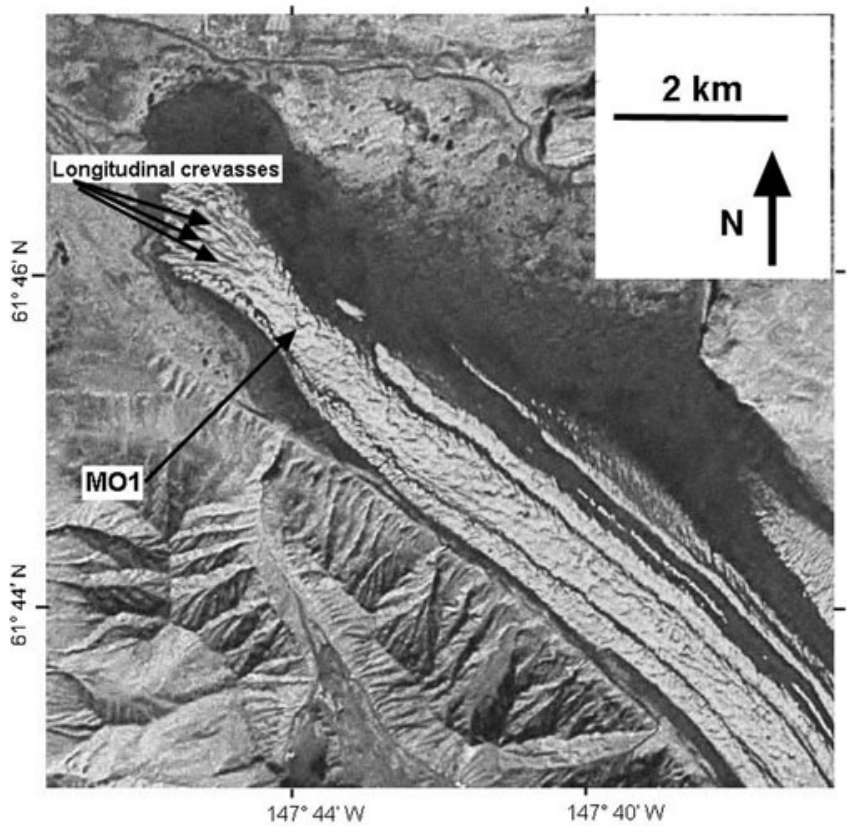

Fig. 9. Landsat image of the terminal zone of Matanuska Glacier showing location of M01.

A large cave entrance (M01) was located $\sim 2.1 \mathrm{~km}$ from the terminus at the confluence of three large supraglacial streams $\left(61^{\circ} 45^{\prime} 47^{\prime \prime} N, 147^{\circ} 43^{\prime} 57^{\prime \prime} \mathrm{W} ;\right.$ Fig. 9). The cave entrance was a vertical slot $\sim 20 \mathrm{~m}$ high and $1.5 \mathrm{~m}$ wide, oriented parallel to the direction of ice flow and nearby longitudinal crevasses (Fig. 10). It plunged down at an angle of $45-55^{\circ}$ and continued steeply downward in a series of waterfalls and plunge pools. A very narrow fracture extended upwards for $\sim 25 \mathrm{~m}$ from the apex of the entrance to the glacier surface. Foliation was continuous on both sides of the fracture, indicating zero relative displacement. Inside the fracture, horizontal pillars of ice were observed to create 'bridges' between the passage walls. This passage was not mapped in detail due to very high melt rates, and loosening of rappel anchors, at the time of our visit.

\section{Interpretation}

The evidence indicates that M01 did not form by the incision and closure of a crevasse-guided canyon (Fountain and Walder, 1998; Gulley, in press). Rather, we conclude that water entering an open fracture where ice was subject to a transverse tensile stress caused deeper parts of the fracture to propagate down-glacier. The ensuing water flow then encouraged further cave enlargement by wall melting and incision. There is no evidence for ponded water in the cave entrance area; recharge to the fracture from the supraglacial streams appears to have been sufficient to initiate hydrofracturing.

\section{SUMMARY AND CONCLUSIONS}

1. The observations reported here demonstrate that englacial drainage systems can develop from hydrologically driven fracturing (hydrofracturing) in a wide range of glaciological regimes.

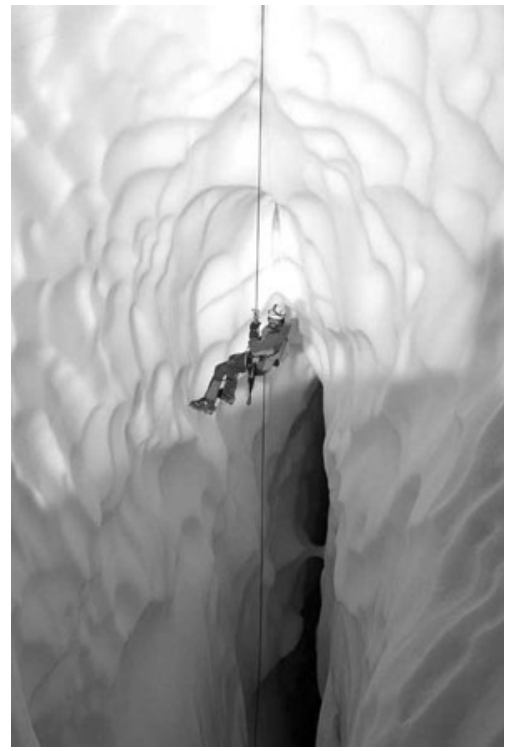

Fig. 10. Entrance of M01, September 2006.

2. In Crystal Cave in Hansbreen, hydrofractures allow surface water to reach the bed through approximately $60 \mathrm{~m}$ of cold ice $\left(\sim-1{ }^{\circ} \mathrm{C}\right)$. The glacier bed is at pressuremelting point, and water from the englacial drainage system flows beneath the glacier into a subglacial conduit. Short-term velocity fluctuations observed on the glacier probably reflect rapid routing of meltwater via moulins formed in this way (Vieli and others, 2004).

3. Once formed, moulins in Crystal Cave remain active for a few years and are progressively modified by water flow. Moulins are bypassed when new fractures are formed upglacier and divert surface water to the bed. However, abandoned moulins may fill with water at times when recharge exceeds the capacity of the system.

4. Hydrofracturing at Crystal Cave is encouraged by high water-recharge rates during drainage of an ephemeral supraglacial lake, combined with longitudinal extension and transverse compression of the ice. Water discharges are likely to remain high following lake drainage, due to the meeting of lateral meltwater channels at the glacier confluence. Ephemeral lakes commonly occur at glacier confluences in Svalbard, and we argue that such sites are favourable locations for hydrofracturing due to the combination of high summer meltwater supply and ice subjected to longitudinal extension and transverse compression (Benn and others, in press).

5. On Khumbu Glacier, englacial drainage was initiated by hydrofracturing in two adjacent supraglacial lake basins in successive years. The basins lie at the up-glacier end of a region of longitudinal compression, where ice flowing from the upper ablation zone decelerates against the slow-moving lower tongue. Fracturing occurred in response to transverse tensile deviatoric stresses in combination with water pressure below the lake surfaces.

6. On Matanuska Glacier, an englacial conduit was initiated by the subsurface extension of a longitudinal crevasse at the up-glacier end of a zone of longitudinal compression. Water entering the crevasse from a 
supraglacial channel was sufficient to initiate hydrofracturing in this locality.

7. At the two conduit systems in polythermal glaciers (Hansbreen and Khumbu Glacier), there is evidence for more than one stage of hydrofracturing and sealing of fractures by freeze-on. At Hansbreen, vertical veins of clear ice in shaft walls show that final breakthrough of the shafts to the glacier bed was preceded by earlier episodes of hydrofracturing, which were halted by freezing. As would be expected, there is no evidence for re-sealing of fractures at the temperate Matanuska Glacier.

8. It has been suggested that supraglacial lakes are necessary for the initiation of hydrofractures (Alley and others, 2005). While lakes played an important role in hydrofracturing at two of our sites, this was not the case at Matanuska Glacier, where a large water supply delivered to a crevasse from a supraglacial channel was sufficient. We hypothesize that, where near-surface deviatoric stresses are relatively low, supraglacial lakes may be necessary for hydrofracturing by providing an elevated head of water and a storage reservoir, but that lakes are not a necessary condition where stresses are sufficient to open deep surface crevasses.

9. Our observations have important implications for glacier hydrologic modelling. First, repeated formation of hydrofractures at similar locations on Hansbreen and Khumbu Glacier suggests that subglacial recharge locations may be stable and predictable. Second, repeat observations at Hansbreen show that near-complete winter flooding of conduits followed by drainage during summer is an annual process. This suggests that, even in cold ice, englacial conduits can survive the winter without freezing shut. The survival of englacial water through the winter months may be encouraged by solute cryoconcentration, but more probably reflects latent heating associated with freeze-on, which will tend to reduce the thermal gradient between the conduit and the ice. Water impounded in relict drainage features is expected to reduce creep closure rates which would be significantly overestimated if conduits were assumed to be dry (Skidmore and Sharp, 1999).

10. The fact that hydrofracturing has played a crucial role in the development of three englacial drainage systems in a diverse sample of glaciers leads us to suspect that it is a very important and widespread process for routing surface water into glaciers and, in favourable circumstances, to glacier beds.

\section{ACKNOWLEDGEMENTS}

Funding was provided by the University Centre in Svalbard, the US National Geographic Society, the US National Speleological Society, The Explorers Club and the American Alpine Club. We thank the personnel at the Polish research station at Hornsund, for hospitality, logistical support and access to unpublished data; S. Keene, L. Nicholson and P. Sherpa for field assistance; and the UK Natural Environment Research Council (NERC) Geophysical Equipment Facility for loan of global positioning system (GPS) units. Constructive comments by L. Copland and an anonymous reviewer are gratefully acknowledged.

\section{REFERENCES}

Alley, R.B., D.E. Lawson, E.B. Evenson, J.C. Strasser and G.J. Larson. 1998. Glaciohydraulic supercooling: a freeze-on mechanism to create stratified, debris-rich basal ice: II. Theory. J. Glaciol., 44(148), 563-569.

Alley, R.B., T.K. Dupont, B.R. Parizek and S. Anandakrishnan. 2005. Access of surface meltwater to beds of sub-freezing glaciers: preliminary insights. Ann. Glaciol., 40, 8-14.

Baker, G.S., D.E. Lawson, E.B. Evenson, G.J. Larson and R.B. Alley. 2003. Glaciogeophysics at Matanuska Glacier, Alaska. [Abstr. C21A-05.] Eos, 84(46), Fall Meet. Suppl.

Benn, D.I., L. Kristensen and J. Gulley. In press. Surge propagation constrained by a persistent subglacial conduit, BakaninbreenPaulabreen, Svalbard. Ann. Glaciol.

Bingham, R.G., P.W. Nienow, M.J. Sharp and S. Boon. 2005. Subglacial drainage processes at a High Arctic polythermal valley glacier. J. Glaciol., 51(172), 15-24.

Blatter, H. and K. Hutter. 1991. Polythermal conditions in Arctic glaciers. J. Glaciol., 37(126), 261-269.

Boon, S. and M. Sharp. 2003. The role of hydrologically-driven ice fracture in drainage system evolution on an Arctic glacier. Geophys. Res. Lett., 30(18), 1916. (10.1029/2003GL018034.)

Catania, G.A., T.A. Neumann and S.F. Price. 2008. Characterizing englacial drainage in the ablation zone of the Greenland ice sheet. J. Glaciol., 54(187), 567-578.

Chesley, T., D.E. Lawson, N. Ham and S. Goetz. 2005. Deformation of pro-glacial sediment due to an advancing ice margin atthe Matanuska Glacier, Alaska. Geol. Soc. Am. Abstr. Prog., 37(5), 83.

Chikita, K., J. Jha and T. Yamada. 1999. Hydrodynamics of a supraglacial lake and its effect on the basin expansion: Tsho Rolpa, Rolwaling Valley, Nepal Himalaya. Arct. Antarct. Alp. Res., 31(1), 58-70.

Copland, L., M.J. Sharp and P.W. Nienow. 2003. Links between short-term velocity variations and the subglacial hydrology of a predominantly cold polythermal glacier. J. Glaciol., 49(166), 337-348.

Das, S.B. and 6 others. 2008. Fracture propagation to the base of the Greenland Ice Sheet during supraglacial lake drainage. Science, 320(5877), 778-781.

Fountain, A.G. and J.S. Walder. 1998. Water flow through temperate glaciers. Rev. Geophys., 36(3), 299-328.

Fountain, A.G., R.W. Jacobel, R. Schlichting and P. Jansson. 2005. Fractures as the main pathways of water flow in temperate glaciers. Nature, 433(7026), 618-621.

Gulley J. In press. Structural control of engacial conduits in the temperate Matanuska Glacier, Alaska, USA. J. Glaciol.

Gulley, J. and D.I. Benn. 2007. Structural control of englacial drainage systems in Himalayan debris-covered glaciers. J. Glaciol., 53(182), 399-412.

Gulley, J.D., D.I. Benn, D. Müller and A. Luckman. 2009. A cutand-closure origin for englacial conduits in uncrevassed regions of polythermal glaciers. J. Glaciol., 55(189), 66-80.

Hagen, J.O., O.M. Korsen and G. Vatne. 1991. Drainage pattern in a subpolar glacier: Brøggerbreen, Svalbard. In Gjessing, Y., J.O. Hagen, K.A. Hassel, K. Sand and B. Wold, eds. Arctic hydrology: present and future tasks. Hydrology of Svalbard hydrological problems in a cold climate. Oslo, Norwegian National Committee for Hydrology, 121-131. (Report 23.)

Hands, K.A. 2004. Downwasting and supraglacial pond evolution on the debris-mantled Ngozumpa Glacier, Khumbu Himal, Nepal. (PhD thesis, University of St Andrews.)

Hansen, O.H. 2001. Internal drainage of some subpolar glaciers on Svalbard. (MSc thesis, University of Bergen.)

Holmlund, P. 1988. Internal geometry and evolution of moulins, Storglaciären, Sweden. J. Glaciol., 34(117), 242-248.

Hooke, R.LeB. 2005. Principles of glacier mechanics. Second edition. Cambridge, etc., Cambridge University Press.

Iken, A. and R.A. Bindschadler. 1986. Combined measurements of subglacial water pressure and surface velocity of 
Findelengletscher, Switzerland: conclusions about drainage system and sliding mechanism. J. Glaciol., 32(110), 101-119.

Joughin, I., S.B. Das, M.A. King, B.E. Smith, I.M. Howat and T. Moon. 2008. Seasonal speedup along the western flank of the Greenland Ice Sheet. Science, 320(5877), 781-783.

Kodama, H. and S. Mae. 1976. Flow of glaciers in the Khumbu region. Seppyo, J. Jpn. Soc. Snow Ice, Special Issue 38, Part 1, $31-36$.

Lawson, D.E., J.C. Strasser, E.B. Evenson, R.B. Alley, G.J. Larson and S.A. Arcone. 1998. Glaciohydraulic supercooling: a freeze-on mechanism to create stratified, debris-rich basal ice. I. Field evidence. J. Glaciol., 44(148), 547-562.

Mae, S. 1976. Ice temperature in the Khumbu Glacier. Seppyo, J. Jpn. Soc. Snow Ice, Special Issue 38, Part 1, 37-38.

Moore, J.C. and 8 others. 1999. High-resolution hydrothermal structure of Hansbreen, Spitsbergen, mapped by ground-penetrating radar. J. Glaciol., 45(151), 524-532.

Nakawo, M., H. Yabuki and A. Sakai. 1999. Characteristics of Khumbu Glacier, Nepal Himalaya: recent changes in the debriscovered area. Ann. Glaciol., 28, 118-122.

Pälli, A., J.C. Moore, J. Jania, L. Kolondra and P. Glowacki. 2003. The drainage pattern of two polythermal glaciers: Hansbreen and Werenskioldbreen in Svalbard. Polar Res. 22(2), 355-371.

Parizek, B.R. and R.B. Alley. 2004. Implications of increased Greenland surface melt under global-warming scenarios: icesheet simulations. Quat. Sci. Rev., 23(9-10), 1013-1027.

Pulina, M. 1984. Glacierkarst phenomena in Spitsbergen. Nor. Geogr. Tidsskr., 38(3-4), 163-168.

Pulina, M. and J. Rehák. 1991. Glacial caves in Spitsbergen. In Eraso, A., ed. Proceedings of the 1st International Symposium of Glacier Caves and Karst in Polar Regions, 1-5 October 1990, Madrid, Spain. Madrid, Instituto Tecnológico Geominero de España, 93-117.

Roberts, M.J., A.J. Russell, F.S. Tweed and O. Knudsen. 2000. Ice fracturing during jökulhlaups: implications for englacial floodwater routing and outlet development. Earth Surf. Process. Landf., 25(13), 1429-1446.
Röthlisberger, H. and H. Lang. 1987. Glacial hydrology. In Gurnell, A.M. and M.J. Clark, eds. Glacio-fluvial sediment transfer: an alpine perspective. Chichester, etc., Wiley, 207-284.

Schroeder, J. 1995. Les moulins du glacier Hans de 1988 à 1992. In Griselin, M., ed. Actes du 3e Symposium International, Cavités Glaciaires et Cryokarst en Régions Polaires et de Haute Montagne, 16 novembre 1994, Chamonix, France. Paris, Les Belles Lettres, 31-39. (Annales Littéraires de I'Université de Besançon 561, Série Géographie 34.)

Schroeder, J. 1998. Hans glacier moulins observed from 1988 to 1992, Svalbard. Nor. Geogr. Tidsskr., 52(2), 79-88.

Seko, K., H. Yabuki, M. Nakawo, A. Sakai, T. Kadota and Y. Yamada. 1998. Changing surface features of Khumbu Glacier, Nepal Himalayas revealed by SPOT images. Bull. Glacier Res. $16,33-41$.

Skidmore, M.L. and M.J. Sharp. 1999. Drainage system behaviour of a High-Arctic polythermal glacier. Ann. Glaciol., 28, 209-215.

Stenborg, T. 1969. Studies of the internal drainage of glaciers. Geogr. Ann., 51A(1-2), 13-41.

Van der Veen, C.J. 1998. Fracture mechanics approach to penetration of surface crevasses on glaciers. Cold Reg. Sci. Technol., 27(1), 31-47.

Van der Veen, C.J. 2007. Fracture propagation as means of rapidly transferring surface meltwater to the base of glaciers. Geophys. Res. Lett., 34(1), L01501. (10.1029/2006GL028385.)

Van de Wal, R.S.W. and 6 others. 2008. Large and rapid meltinduced velocity changes in the ablation zone of the Greenland Ice Sheet. Science, 321(5885), 111-113.

Vieli, A., J. Jania, H. Blatter and M. Funk. 2004. Short-term velocity variations on Hansbreen, a tidewater glacier in Spitsbergen. J. Glaciol., 50(170), 389-398.

Wessels, R.L., J.S. Kargel and H.H. Kieffer. 2002. ASTER measurement of supraglacial lakes in the Mount Everest region of the Himalaya. Ann. Glaciol., 34, 399-408.

Willis, I.C. 1995. Intra-annual variations in glacier motion: a review. Progr. Phys. Geogr., 19(1), 61-106.

Zwally, H.J., W. Abdalati, T. Herring, K. Larson, J. Saba and K. Steffen. 2002. Surface melt-induced acceleration of Greenland ice-sheet flow. Science, 297(5579), 218-222. 